\title{
REVIEW
}

\section{Understanding the pathology of schizophrenia: recent advances from the study of the molecular architecture of postmortem CNS tissue}

\section{B Dean}

Postgrad Med J 2002;78:142-148

The use of central nervous system (CNS) tissue obtained postmortem has long underpinned efforts to understand the neurobiology of schizophrenia, but the ability to use such tissue in conjunction with a wide variety of methodologies has seen a renaissance of interest in this area of research. Recent findings have shown changes in markers in a number of neurotransmitter systems in the brains of subjects with schizophrenia which include the dopaminergic, serotonergic, cholinergic, glutamatergic, and GABAergic systems of the CNS. Many of these changes also appear to be regionally specific, and abnormalities in non-neurotransmitter specific pathways have been found in schizophrenia. Changes in the neurotransmitter release pathways in schizophrenia may be important in the pathology of the illness, and recent findings suggest that abnormalities in the Wnt pathway, which controls transcription selectivity in cells, may be involved. Studies using CNS material obtained postmortem clearly show that the pathology of schizophrenia is complex while the polygenetic nature of the illness may be adding to this complexity.

Correspondence to: Dr Brian Dean, Rebecca L Cooper Research Laboratories, The Mental Health Research Institute of Victoria, Locked Bag 11 , Parkville, Victoria 3052, Australia;

bdean@mhri.edu.au

Submitted 22 June 2001 Accepted

22 October 2001
R esearch on tissue obtained postmortem has been an important component of efforts to understand the pathology of schizophrenia. With the realisation that such tissue can be used in conjunction with a wide variety of technologies and probes there has been a renaissance in the use of such tissue to understand the changes in the molecular architecture in the central nervous system (CNS) that underlie schizophrenia. It is therefore timely to review the progress made in identifying proteins and pathways that may be involved in the pathology of schizophrenia.

\section{NEUROTRANSMITTER RECEPTOR AND TRANSPORTERS IN SCHIZOPHRENIA}

A major component of the studies using postmortem CNS tissue have been directed towards understanding the role of neurotransmitter receptors and transporters in the pathology of schizophrenia. This is because these sites are amenable to manipulation by therapeutic agents and, in many cases, are the sites of action of drugs with proved antipsychotic activity. ${ }^{1}$ Moreover, it is mainly neuropharmacological observations using drugs that target neurotransmitter receptors and transporters that have underpinned the formulation of hypotheses on the pathology of schizophrenia. ${ }^{2}$ These hypotheses have implicated the dopaminergic, serotonergic, cholinergic, glutamatergic, or gamma aminobutyric acid (GABA)ergic systems in the pathology of schizophrenia.

\section{Studies on the dopaminergic systems}

The findings that antipsychotic drugs are dopamine $\mathrm{D}_{2}$ receptor antagonists and that dopamine receptor agonists can cause or exacerbate psychoses has underpinned the long standing dopamine hypothesis of schizophrenia. ${ }^{2}$ This hypothesis proposes that overactive dopaminergic pathways in the CNS are central to the pathology of the illness. Recent work on dopaminergic systems, using postmortem tissue, has mainly focused on levels of mRNA for the different dopamine receptors in the cortex of subjects with schizophrenia. Thus, one study reported an increase in mRNA for the dopamine $\mathrm{D}_{\text {2longer }}$ receptor in the frontal cortex of subjects with schizophrenia. ${ }^{3}$ This finding, along with the report of an increase in mRNA for the dopamine $\mathrm{D}_{4}$ receptor in the cortex but not caudate from subjects with schizophrenia, ${ }^{4}$ would suggest that there may be abnormalities in the expression of cortical dopamine receptors associated with the illness. Unfortunately, the lack of specific radioligands for the dopamine $\mathrm{D}_{4}$ and $\mathrm{D}_{\text {2longer }}$ receptors means that it is not possible to determine if these changes in levels of expression have resulted in changes in receptor protein in the cortex from subjects with schizophrenia. This is important as there appears to be no change in the density of global dopamine $\mathrm{D}_{2}$-like or dopamine $\mathrm{D}_{1}$-like receptors in the frontal cortex from subjects with schizophrenia.

\section{Studies on the serotonergic systems}

There has been an increasing acceptance that antipsychotic drugs that bind to both the dopamine $\mathrm{D}_{2}$-like receptor family and the serotonin $(5 \mathrm{HT})_{2 \mathrm{~A}}$ receptor have improved clinical

Abbreviations: AMPA,

$\alpha$-amino-3-hydroxy-5-methyl-4-isoxazolepropionic acid; CNS, central nervous system; GABA, gamma aminobutyric acid; GSK, glycogen synthase kinase; $5 \mathrm{HT}$; serotonin; $M$, muscarinic; mGluR, metabotropic glutamate receptors; NMDA, N-methyl-D-aspartate; SNAP-25, synaptosomal associated protein- 25 
outcomes. ${ }^{6}$ This has meant that increasing attention has been paid to the status of serotonergic markers in postmortem tissue from subjects with schizophrenia. There are now a number of reports of a decreased density of cortical $5 \mathrm{HT}_{2 \mathrm{~A}}$ receptors in schizophrenia (for review see Dean ${ }^{7}$ ), a change that is not part of a generalised change in serotonergic markers in the frontal cortex of subjects with schizophrenia. ${ }^{8}$ Increasingly, evidence suggests that the decrease in cortical $5 \mathrm{HT}_{2 \mathrm{~A}}$ receptors in schizophrenia is related, at least in part, to the pathology of the illness rather than an effect of drug treatment during life. This evidence includes the fact that changes in $5 \mathrm{HT}_{2 \mathrm{~A}}$ receptors in cortex from humans and rats treated with the same antipsychotic drugs do not marry, ${ }^{9}$ that levels of mRNA for the $5 \mathrm{HT}_{2 \mathrm{~A}}$ receptors are only decreased in the prefrontal cortex from subjects not treated with antipsychotic drugs for six months before death ${ }^{10}$ and that cortical $5 \mathrm{HT}_{2 \mathrm{~A}}$ receptors are not altered in subjects with bipolar disorder receiving antipsychotic drugs up to death. ${ }^{11}$ However, concluding that all changes in $5 \mathrm{HT}_{2 \mathrm{~A}}$ receptors in postmortem tissue from subjects with schizophrenia are related to the pathology of the illness needs to be tempered by the observation that, in the planum temporale, complex changes in density of $5 \mathrm{HT}_{2 \mathrm{~A}}$ receptors appear to have arisen because of both pathological and antipsychotic drug effects. ${ }^{12}$

It would be predicted that if the $5 \mathrm{HT}_{2 \mathrm{~A}}$ receptor was central to the pathology of schizophrenia there would be an association between a specific mutation in the gene for the $5 \mathrm{HT}_{2 \mathrm{~A}}$ receptor and the illness. Using DNA from peripheral tissue, a number of studies have suggested that mutations in the gene for the $5 \mathrm{HT}_{2 \mathrm{~A}}$ receptor are associated with schizophrenia. ${ }^{13}$ By contrast, studies using tissue obtained postmortem have failed to show an association between specific mutations in the gene for the $5 \mathrm{HT}_{2 \mathrm{~A}}$ receptor with either schizophrenia or the density of the receptor in the cortex. ${ }^{14}{ }^{15}$ Therefore, data from postmortem tissue do not favour the argument that mutations in the $5 \mathrm{HT}_{2 \mathrm{~A}}$ receptor are either associated with schizophrenia or modulate the levels of the receptor in human cortex. Hence further efforts are required to identify the mechanism that has reduced the density of cortical $5 \mathrm{HT}_{2 \mathrm{~A}}$ receptors in schizophrenia.

\section{Studies on the cholinergic systems}

A growing understanding that aberrations in CNS functions that are modulated by the cholinergic system could cause some of the symptoms of schizophrenia has led to the suggestion that changes in this system must be involved the pathology of the illness. ${ }^{16}$ In particular, recent studies have focused on the receptors through which acetylcholine can exert its effects in the CNS, which are divided into two broad families, the nicotinic receptors and the muscarinic receptors. ${ }^{17}$ The receptors can be delineated by their ability to bind nicotine and muscarine respectively and have differing modes of action; the nicotinic receptors are gated ion channels and the muscarinic receptors are G-protein linked.

Confounding issues affecting the study of nicotinic receptors in postmortem tissue are that the inhalation of nicotine increases levels of the nicotinic receptors ${ }^{18}$ and there is an increased level of nicotine self administration in schizophrenia. ${ }^{19}$ However, decreased levels of nicotinic receptors have been reported the hippocampus, cortex, and caudate from subjects with schizophrenia, ${ }^{18}$ which would therefore seem to be an effect independent of nicotine self administration. In another study of the caudate a decrease in nicotinic receptors was reported in schizophrenia despite increased levels of the receptors being present in tissue from control subjects who had a history of smoking. ${ }^{20}$ One study has reported levels of nicotinic receptors in the striatum from a group of elderly schizophrenic subjects who had received long term treatment with antipsychotic drugs to be above levels in tissue from the control group as whole, and members of that group who had a history of smoking. ${ }^{21}$ The data from this study could indicate that either long term antipsychotic drug treatment up-regulates the levels of nicotine receptors, or that there could be an effect of increased smoking in subjects with schizophrenia. The absence of an increase in nicotinic receptors in tissue from rats treated for six weeks with the antipsychotic drug haloperidol would argue against such treatments increasing the same receptors in human tissue. ${ }^{18}$ In summary, while the weight of current data support the argument that there is a decrease in nicotinic receptors in the CNS of subjects with schizophrenia, the pathological significance of the finding needs to be elucidated. However, this finding would add credence to the suggestion that subjects with schizophrenia may self medicate with nicotine to alleviate symptoms caused by abnormalities in nicotinic related pathways associated with the illness.

One of the major impediments to studying the muscarinic receptors in the human CNS has been the lack of receptor specific radioligands. However, with the use of selective radioligands and displacing agents it is now possible to study the density of combinations of muscarinic receptors in the postmortem CNS tissue. Using this approach, a decrease in muscarinic $_{1 / 4}\left(M_{1 / 4}\right)$ receptors have been reported in the caudate putamen $^{22}$ and hippocampus ${ }^{23}$ from subjects with schizophrenia. The change in $\mathrm{M}_{1 / 4}$ receptors in the caudate was not accompanied by a change in mRNA encoding the $M_{1}$ receptor in tissue from the same donors. ${ }^{24}$ This could indicate either the decrease in radioligand binding was due to a change in the density of only the $\mathrm{M}_{4}$ receptor or that the decrease in receptor protein was not accompanied by a change in levels mRNA for that receptor.

Using a similar approach, a decrease of $\mathrm{M}_{2 / 4}$ receptors has also been reported in the caudate-putamen in schizophrenia. ${ }^{25}$ Significantly, mRNA for the $\mathrm{M}_{2}$ receptor was either absent, or present at very low levels, in the caudateputamen from the individuals used in the $M_{2 / 4}$ radioligand study. ${ }^{24}$ One conclusion that can be drawn from these data is that there are no $\mathrm{M}_{2}$ receptors in the human caudate-putamen and hence the decrease in radioligand binding was solely due to a decrease in $\mathrm{M}_{4}$ receptors. This proposal would be in line with one possible outcome from the study of $M_{1 / 4}$ receptor binding in the caudate-putamen. Alternatively, $\mathrm{M}_{2}$ receptors could be present on innervating neurons (hence the absence of mRNA as the cell bodies containing the mRNA would not be present in the caudate-putamen). If this proves to be the case, then this would be evidence to support the argument that $\mathrm{M}_{2}$ receptors act as autoreceptors in the caudate-putamen and that either $M_{2}$ or $M_{4}$ receptors could be decreased in the caudate-putamen from subjects with schizophrenia.

\section{Studies on the glutamatergic systems}

The ability of phencyclidine, a glutamate receptor ion channel blocker, to induce or exacerbate a schizophrenic-like psychoses, has been central to the hypotheses that changed glutamatergic function is involved in the pathology of schizophrenia. ${ }^{26}$ This has led to an extensive investigation of glutamatergic markers in postmortem CNS tissue from subjects with schizophrenia. There are two major families of glutamate receptors. One family is a group of ionotropic glutamate receptors made up of the $N$-methyl-D-aspartate (NMDA), the $\alpha$-amino-3hydroxy-5-methyl-4-isoxazolepropionic acid (AMPA) and the kainate receptors. All these receptors are made up of a combination of specific subunits, ${ }^{27}$ which assemble in the membrane to form cation conductance channels. The other family of receptors are known as the metabotropic receptors and are G-protein coupled receptors. ${ }^{28}$

Due to the absence of radioligands for the metabotropic glutamate receptors, studies have thus far focused on levels of mRNA encoding for the eight different metabotropic glutamate receptors (mGluR $1-8) .{ }^{29}$ One study has reported no 
change in the levels of mRNA encoding any of the eight metabotropic glutamate receptors in the thalamus from subjects with schizophrenia. ${ }^{29}$ Another study has reported no change in levels of mRNA encoding the mGluR 3 and 5 in Brodmann's areas 9 and 10 but did show a decrease in mRNA for the mGluR 5, but not mGluR 3, in Brodmann's area 11 from subjects with schizophrenia. ${ }^{28}$ These early findings suggest that there may be regionally discrete differences in levels of metabotropic receptors in the CNS of subjects with schizophrenia.

As phencyclidine blocks the ion channel of the NMDA receptor it is significant that this receptor has been reported as decreased in the cornu Ammonis (CA) 3 region of the hippocampus from subjects with schizophrenia. ${ }^{30}$ However, this finding was not replicated in a study which also failed to show any major changes in AMPA or kainate receptors in the hippocampus from subjects with schizophrenia. ${ }^{31}$ The NMDA receptor contains a number of functional binding domains and it has been suggested that one of these domains, the glycine binding site, is decreased in the thalamus from subjects with schizophrenia without a change in the overall density of the NMDA receptor in that region. ${ }^{32}$ Adding to the argument that the glycine binding site on the NMDA receptor may be altered in schizophrenia is a report that the site is increased in the putamen, but not caudate or nucleus accumbens, from subjects with schizophrenia. ${ }^{33}$ As the differential presentation of these bindings sites is a function of subunit assembly, these data could suggest that NMDA receptors containing different subunit assemblies are present in the CNS of subjects with schizophrenia.

At present, glutamate receptor subunit specific radioligands are not available and thus non-radioligand binding approaches must be used to address the hypothesis of glutamate receptor subunit dysregulation in schizophrenia. In the study that reported no major changes in the density of ionotropic receptors in the hippocampus from subjects with schizophrenia, ${ }^{31}$ levels of mRNA for the NRl subunit of the NMDA receptor were found to be decreased in the dentate gyrus from subjects with schizophrenia and tended to be lower $(-25 \%)$ in the CA3 region. By contrast, mRNA for the NR2B subunit of the NMDA receptor was higher in the CA2 region from the schizophrenic subjects. Studies in the thalamus have also reported lower levels of mRNA for the NR1 subunit of the NMDA receptor in the dorsomedial and central medial nuclei. ${ }^{32}$ In addition, mRNA for the NR2B subunit was lower in the central medial nucleus and mRNA for the NR2C subunit was lower in the anterior, dorsomedial, lateral medial, and central medial nuclei. This study also reported lower levels of mRNA for the gluRl subunit of the AMPA receptor in the dorsomedial nucleus with lower levels of gluRl and gluR3 subunits being detected in central medial nuclei of subjects with schizophrenia. Finally, mRNA from the KA2 subunit of the kainate receptor was decreased in anterior, dorsomedial, lateral dorsal, central medial, and ventral nuclei of the thalamus from subjects with schizophrenia.

In contrast to studies in the thalamus and hippocampus, it has been reported that neither AMPA receptor radioligand binding nor levels of mRNA for AMPA receptor subunits are altered in the frontal cortex of subjects with schizophrenia. ${ }^{34}$ However, levels of mRNA for the NRl, gluRl, gluR7, and KAl subunits of glutamate receptors have been reported as being decreased in the cortex of schizophrenic subjects not receiving antipsychotic drugs within six months of death. ${ }^{35}$ Significantly, in this study decreased levels of mRNA for subunits of the glutamate receptors were not observed in subjects who were receiving antipsychotic drugs up until death.

In conclusion, current data on ionotropic receptors would suggest that there are regionally specific changes in receptor subunit expression in subjects with schizophrenia. However, one confounding issue is data from one study that suggest that levels of mRNA encoding subunits of the ionotropic glutamate receptors may be affected by antipsychotic drug treatment..$^{35}$ Moreover, changes in levels of mRNA encoding subunit of the ionotropic receptors is not necessarily associated with changes in radioligand binding to those receptors. This raises the possibility that the changes in rates of expression of receptor subunits do not affect the density of fully assembled, functional receptors and therefore may be of minimal or no physiological consequence. Further studies will need to be completed to attempt to address this hypothesis.

\section{Studies on the GABAergic systems}

Several lines of evidence implicated the GABAergic system in the pathology of schizophrenia, not the least of which are reports showing changes in the $\mathrm{GABA}_{\mathrm{A}}$ receptor in various regions of the CNS from subjects with schizophrenia. ${ }^{7}$ The $\mathrm{GABA}_{\mathrm{A}}$ receptor belongs to the ligand gated ion channel receptors that are made up of multiple subunits. The study of mRNA encoding the different subunits has now extended original findings on radioligand binding to show an increase in levels of mRNA encoding the $\alpha-1$ subunit of the $\mathrm{GABA}_{\mathrm{A}}$ receptor in Brodmann's areas 9 and 10 from subjects with schizophrenia. ${ }^{36}$ This study also reported a decrease in the concentration of GABA and an increase in the levels of mRNA encoding the GABA transporter-1. These two findings raise the possibility that an increase in the GABA transporter could be resulting in changes in levels of extracellular GABA and a subsequent change in $\mathrm{GABA}_{\mathrm{A}}$ receptor expression. Against this argument is the finding that the absolute levels of mRNA for the GABA transporter-1 was not altered in Brodmann's areas 9 and 10 from subjects with schizophrenia. ${ }^{37}$ However, this study did find a decrease in the number of neurons containing the GABA transporter- 1 in layers 1 through 5 in the tissue from the subjects with schizophrenia. The consequence of a loss of GABA transporter-1 containing neurons has yet to be elucidated.

Further data to support the argument that there are changes in expression of $\mathrm{GABA}_{\mathrm{A}}$ receptor subunit in schizophrenia are the finding that there is a marked decrease in levels of mRNA encoding for the short form of the $\gamma 2$ subunit of the $\mathrm{GABA}_{\mathrm{A}}$ receptor in the prefrontal cortex from schizophrenia. ${ }^{38}$ This decrease was not accompanied by a change in mRNA encoding the long form of that receptor subunit. These data seem to add weight to the argument that altered $\mathrm{GABA}_{\mathrm{A}}$ receptor subunit expression and assembly may be important in the pathology of schizophrenia.

\section{Studies on the cannabinoid systems}

The argument that subjects may self medicate with various compounds may be relevant to findings from a study of cannabis $_{1}$ receptors in postmortem tissue from subjects with schizophrenia. ${ }^{39}$ This study reported that cannabis ${ }_{1}$ receptors were increased in the frontal cortex of subjects with schizophrenia, whether or not the subjects had used cannabis close to death. By contrast, cannabis 1 receptors were increased in the caudate-putamen from subjects who had used cannabis close to death, whether or not they had schizophrenia. These findings could be interpreted as preliminary data to suggest that cannabis use associated with schizophrenia may represent a form of self medication. However, a much more extensive study of the cannabinoid system in the CNS of subjects with schizophrenia is required before significant weight can be given to such an argument.

\section{EVIDENCE FOR CHANGED NON-NEUROTRANSMITTER SPECIFIC PATHWAYS IN THE PATHOLOGY OF SCHIZOPHRENIA}

A review of the findings relating to neurotransmitter receptors and transporters in postmortem CNS tissue from subjects with schizophrenia clearly shows that multiple pathways in multiple regions of the CNS are affected by the illness (table 
Box 1: Findings on neurotransmitter systems in schizophrenia

- Postmortem studies suggest there is severe disruption to a number of neurotransmitter systems in the CNS of subjects with schizophrenia including the dopaminergic, serotonergic, cholinergic, glutamatergic, and GABAergic systems.

- Changes in neurotransmitter systems appear to be regionally specific with the frontal cortex, hippocampus, and thalamus being particularly affected.

- Changes identified in receptors that bind nicotine and the reactive component of cannabis may add weight to the argument that subjects with schizophrenia may attempt to "self medicate" using these compounds.

1). One explanation for such extensive and apparently diverse changes could be that proteins generically involved in all neurotransmitter systems may be altered in schizophrenia. One such group of proteins are those critical to neurotransmitter release and include synaptosomal associated protein-25 (SNAP-25), synaptobrevin, synaptotagramin, syntaxin, synapsin, and synaptophysin. ${ }^{40}$ Specific interactions between these and other proteins ensure the fusion of synaptic vesicles with the synaptic membrane and subsequent release of neurotransmitter. ${ }^{41}$

Synaptophysin has now been the focus of a number of studies in schizophrenia. A decrease in the levels of mRNA has been reported in CA4 and CA3 of the hippocampus and layers III and V/VI of the entorhinal cortex, however this change was also present in tissue from a group of subjects with mixed psychiatric illnesses other than schizophrenia. ${ }^{42}$ By contrast, it has been reported that levels of mRNA for synaptophysin are not altered in the prefrontal cortex from subjects with schizophrenia. ${ }^{43}$ These two studies raise the possibilities that changes in synaptophysin may be regionally, but not disease, specific.

The findings regarding the mRNA encoding for synaptophysin appear to contrast with studies of synaptophysin protein which, for example, show an increase in synaptophysin immunoreactivity in the granule cell layer of the dentate gyrus. ${ }^{44}$ However, another study has shown a decrease in synaptophysin protein in the gyrus cinguli and hippocampus, but not the thalamus, of subjects with schizophrenia. ${ }^{45}$ The same group have also reported that synaptophysin levels are decreased in the thalamus from the left, but not right, hemisphere ${ }^{46}$ raising the possibility of lateralised changes in the protein in schizophrenia. In the frontal cortex, a significant decrease in synaptophysin levels in schizophrenic subjects dying of natural causes has been reported but this difference was not detected in the same CNS region from schizophrenic subjects who died by suicide. ${ }^{47}$ The apparent discrepancy between findings on protein and mRNA levels has not been resolved by a study examining levels of synaptophysin mRNA and protein in frontal cortex from subjects with schizophrenia collected in two different locations. ${ }^{48}$ This study showed that there was a robust decrease in synaptophysin protein and mRNA in Brodmann's area 17, but not areas 9/46, 24 or 22 , from subjects with schizophrenia collected from only one of the two locations. Overall, evidence would seem to support a change in synaptophysin in the CNS from subjects with schizophrenia but the extent and consequence of these changes are not yet clear.

In a study which examined levels of mRNA for synaptophysin, synaptotagmin I, synaptobrevin I, SNAP-25, and syntaxin $1 \mathrm{~A}$ it was reported that levels of mRNA for these proteins

Table 1 A summary of changes in different regions of the central nervous system from subjects with schizophrenia

\begin{tabular}{|c|c|c|c|c|}
\hline Brain region & Nuclei & Neurotransmitter & Measurement & Finding \\
\hline Caudate-putamen & Putamen & Acetylcholine & $\begin{array}{l}\text { Radioligand binding } \\
\text { mRNA } \\
\text { Radioligand binding }\end{array}$ & $\begin{array}{l}\uparrow \text { and } \downarrow \text { nicotinic receptor } \\
\downarrow M_{1 / 4} \text { receptors } \\
\downarrow M_{2 / 4} \text { receptors } \\
\text { No change in } M_{1} \text { or } M_{2} \text { receptors } \\
\uparrow \text { Glycine binding site: NMDA receptor }\end{array}$ \\
\hline Frontal cortex & $\begin{array}{l}\text { BA } 9 \text { and } 10 \\
\text { BA } 9 \text { and } 10\end{array}$ & $\begin{array}{l}\text { Dopamine } \\
\text { Serotonin } \\
\text { Acetylcholine } \\
\text { Glutamate } \\
\text { GABA } \\
\text { Anandamide }\end{array}$ & $\begin{array}{l}\text { mRNA } \\
\text { Radioligand binding } \\
\text { mRNA }\end{array}$ & $\begin{array}{l}\uparrow D_{2 \text { longer }} \text { receptor } \\
\uparrow \mathrm{D}_{4} \text { receptor } \\
\downarrow 5 \mathrm{HT}_{2 \mathrm{~A}} \text { receptor: antipsychotic drug free subjects } \\
\downarrow 5 \mathrm{HT}_{2 \mathrm{~A}} \text { receptor binding } \\
\downarrow \text { Nicotinic receptor } \\
\downarrow \mathrm{mGluR5} \\
\downarrow N R 1 \text { subunit : NMDA receptor } \\
\downarrow \text { gluR } 1 \text { and gluR7 subunit: AMPA receptor } \\
\downarrow \mathrm{KA} 1 \text { subunit: kainate receptor } \\
\downarrow \alpha 1 \text { subunit: GABA } \mathrm{A}_{\mathrm{A}} \text { receptor } \\
\downarrow \gamma 2 \text { subunit: GABA } \mathrm{A} \text { receptor } \\
\uparrow \mathrm{GABA} \text { transporter- } 1 \\
\uparrow \text { Cannabis, receptor }\end{array}$ \\
\hline Hippocampus & $\begin{array}{l}\text { CA3 } \\
\text { Dentate } \\
\text { CA2 }\end{array}$ & $\begin{array}{l}\text { Acetylcholine } \\
\text { Glutamate }\end{array}$ & mRNA & $\begin{array}{l}\downarrow \text { Nicotinic receptor } \\
\downarrow M_{1 / 4} \text { receptors } \\
\downarrow \text { Or no change in NMDA receptor } \\
\downarrow N R 1 \text { subunit of NMDA receptor } \\
\uparrow N R 2 B \text { subunit of NMDA receptor }\end{array}$ \\
\hline Planum temporale & & Serotonin & Radioligand binding & $\downarrow 5 \mathrm{HT}_{2 \mathrm{~A}}$ receptor binding \\
\hline Thalamus & $\begin{array}{l}\text { Dorsomedial and central } \\
\text { Central medial } \\
\text { Anterior, dorsomedial, lateral } \\
\text { medial and central medial } \\
\text { Dorsomedial and central } \\
\text { Central } \\
\text { Anterior, dorsomedial, lateral } \\
\text { dorsal, central medial and ventral }\end{array}$ & Glutamate & $\begin{array}{l}\text { mRNA } \\
\text { Radioligand binding } \\
\text { mRNA }\end{array}$ & $\begin{array}{l}\text { No change in metabotropic glutamate receptors } \\
\downarrow \text { Glycine binding site on NMDA receptor } \\
\downarrow \text { NR } 1 \text { subunit of the NMDA receptor } \\
\downarrow \text { NR2B subunit of the NMDA receptor } \\
\downarrow \text { NR2C subunit of the NMDA receptor } \\
\\
\downarrow \text { gluR } 1 \text { subunit AMPA receptor } \\
\downarrow \text { gluR3 subunit AMPA receptor } \\
\downarrow \text { KA2 subunit of kainate receptor }\end{array}$ \\
\hline
\end{tabular}




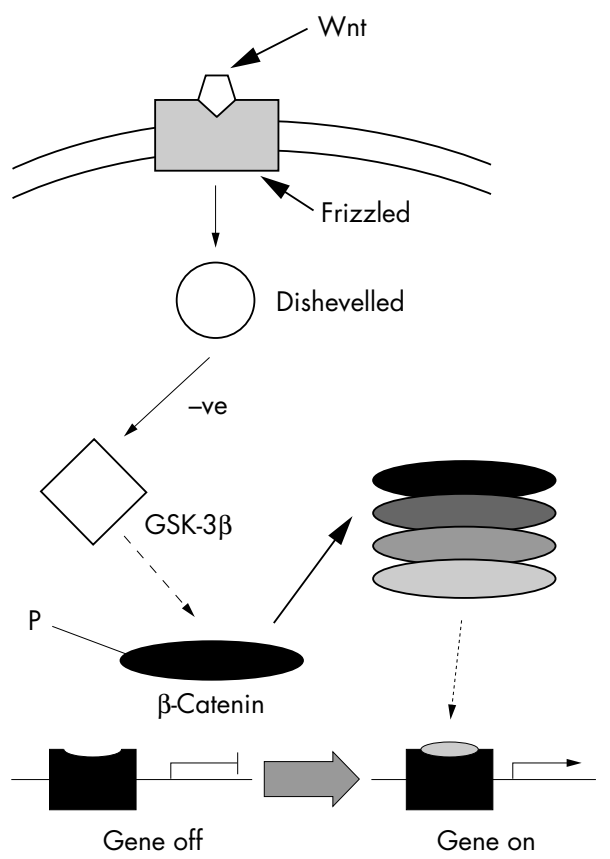

Figure 1 A simplified schematic outlining of the Wnt pathway. Activation of the Wnt pathway occurs when Wnt binds to the frizzled receptors. One mechanism by which the frizzled receptor can transmit the Wnt signal is by the recruitment or release of dishevelled proteins. The dishevelled proteins are a family of cytoplasmic proteins that contain putative protein-protein interactive domains. Currently, it is thought that one of the actions of a recruited or released dishevelled protein is to inhibit the activity of GSK-3 3 . Inhibiting the activity of this enzyme in turn reduces the ability of the enzyme to promote instability of $\beta$-catenin in a cell. The resulting increased levels of $\beta$-catenin in the cell are then thought to bind to transcription factor-DNA binding factors which results in an activation of gene transcription (for more complete reviews on Wnt pathways see Dale ${ }^{50}$ and Kuhl et a ${ }^{10}$ ).

were increased in "younger" subjects with schizophrenia (58-79 years) but were not altered in "older" subjects (80-95 years) with the illness. ${ }^{49}$ Another study has shown decreases in SNAP-25 in Brodmann's areas 10 and 20, no change in that protein in Brodmann's area 17, and an increased SNAP-25 in Brodmann's area 9 from subjects with schizophrenia. ${ }^{40}$ Hence it would currently seem that there are changes in multiple proteins involved in neurotransmitter release cascades and this could be an important component in the pathology of schizophrenia. This argument is strengthened by the demonstration that rab3a, a synaptic vesicle associated protein, has been shown to be present in decreased levels in the thalamus ${ }^{45}$ with increased levels of mRNA for the protein present in left superior temporal gyrus from a group of schizophrenic subjects between the ages of 58 and 79 years of age. $^{49}$

One interesting line of research that has unfolded recently relates to proteins in the Wnt pathway in CNS tissue obtained postmortem. The Wnt pathway is a highly conserved developmental pathway that appears to be involved in determining the fate of cells in the central nervous system of most eukaryotes. $^{50}$ The Wnt pathway ultimately plays a part in switching on and off of gene transcription (fig l), which then influences many cellular functions. Significantly, an increase in the number of Wnt-1 immunoreactive neurons has been demonstrated in the pyramidal cell layer of the CA 3 and CA 4 regions of the hippocampus from subjects with schizophrenia. ${ }^{51}$ Further findings implicating the $W n t$ pathway in the pathology of schizophrenia come from two reports showing a decrease in glycogen synthase kinase (GSK)-3 $\beta$, a critical protein in the Wnt pathway (fig l) in the prefrontal
Box 2: Findings on non-neurotransmitter specific proteins in schizophrenia

- Changes in proteins involved in the release of neurotransmitters could be involved in the pathological processes of schizophrenia.

- Such changes could cause the changes in proteins that are thought to be neurotransmitter systems specific that have been observed across systems.

- Changes in the Wnt pathway implicate this pathway in the pathology of schizophrenia.

- Changes in this pathway could have profound effects on brain development and function.

\section{Box 3: The syndrome of schizophrenia}

- Schizophrenia is likely to be a syndrome and its symptoms could be generated by different pathologies.

- As is proving the case with Alzheimer's disease, it is likely that abnormalities in different pathways of the CNS will account for the onset of symptoms in subsets of individuals with schizophrenia.

cortex of subjects with schizophrenia. ${ }^{52}{ }^{53}$ Notably one of these studies also reported that other components of the Wnt pathway, $\beta$-catenin and dishevelled-2, were not altered in schizophrenia. ${ }^{53}$ However, as GSK- $3 \beta$ appears to be a rate limiting step in this critical pathway, ${ }^{50}$ the change in this protein alone could have significant pathological consequences for subjects with schizophrenia.

Clearly further study is warranted to determine the extent of changes in the Wnt pathway in postmortem CNS from subjects with schizophrenia and to understand how this pathway may be involved in the pathological processes leading to the onset of the illness.

In addition to the more established lines of experiments on neurotransmitter release and Wnt pathway there are early reports of changes in lipoproteins, ${ }^{54}$ cell guidance proteins such as reelin, ${ }^{55}$ and proteins in the apoptotic pathways such as $\mathrm{Bcl}-2^{56}$ in the CNS from subjects with schizophrenia. Changes in these key pathways in schizophrenia would be expected to profoundly disrupt CNS functioning. However, there is now a growing body of data that suggests that changes in non-neurotransmitter specific proteins could be important in the underlying pathology of schizophrenia. It is still not clear whether the extensive changes in neurotransmitter associated proteins are simply a consequence of changes in such proteins.

\section{CONCLUDING REMARKS}

In summary, research using postmortem tissue has confirmed that there are multiple changes in the molecular cytoarchitecture of the CNS from subjects with schizophrenia. The challenge is to determine if these changes result from multiple abnormalities in gene expression or are due to a change in a few critical proteins that would produce profound disruption of CNS functioning. Importantly, when considering the outcomes of the study of postmortem CNS tissue associated with schizophrenia, it is important to note that it is most likely this syndrome has a polygenetic basis. ${ }^{57}$ Thus, it could be that abnormalities in different pathways may be involved in the different forms of the illness. As the genetic basis of schizophrenia unfolds, ${ }^{13}$ it would seem that pathways of pathology associated with specific genetically homogenous populations of subjects with schizophrenia will become apparent. Support for this argument comes from disorders of the CNS, such as Alzheimer's disease, ${ }^{58} 59$ where it has become 


\section{Key references}

- Dean B. Signal transmission, rather than reception, is the underlying neurochemical abnormality in schizophrenia. Aust N Z J Psychiatry 2000;34:560-9.

- Dale TC. Signal transduction by the Wnt family of ligands. Biochem J 1998:329:209-23.

- Riley BP, McGuffin P. Linkage and associated studies of schizophrenia. Am J Med Genet 2000;97:23-44.

- Meltzer HY. Biochemical studies in schizophrenia. Schizphr Bull 1976;2:10-18.

- Turner KM, Burgoyne RD, Morgan A. Protein phosphorylation and the regulation of synaptic membrane traffic. Trends Neurosci 1999;22:459-64.

apparent that changes in different CNS proteins can result in the presentation of apparently homogenous symptoms as end points.

\section{medicate? \\ (A) Dopamine receptors \\ (B) Nicotinic receptors \\ (C) Cannabis ${ }_{1}$ receptors \\ (D) Serotonin receptors}

QUESTIONS (ANSWERS AT END OF PAPER)

Q1: Abnormalities in which receptors add weight to the argument that subjects with schizophrenia may self

Q2: In which neurotransmitter systems has there been changes in the presynaptic transporter associated with schizophrenia?

(A) Serotonin

(B) Glutamate

(C) GABA

(D) Acetylcholine

Q3: Which hypothesis on the pathology of schizophrenia was based in part on the action of antipsychotic drugs?

(A) Glutamate

(B) GABA

(C) Dopamine

Q4: Which proteins, which have been shown to be altered in the CNS from subjects with schizophrenia, are involved in the processes of neurotransmitter release?

(A) Wnt

(B) SNAP-25

(C) Serotonin ${ }_{2 \mathrm{~A}}$ receptor

(D) rab3a

Q5: Are the many and varied findings in schizophrenia likely to be due to

(A) Problems with diagnoses

(B) An inappropriate use of CNS material

(C) Genetic variability

(D) The complexity of the human CNS

\section{REFERENCES}

1 Goodman AB, Pardee AB. Meeting report; "Molecular neurobiological mechanisms in schizophrenia: seeking a synthesis". Biol Psychiatry 2000;48:173-83.

2 Meltzer HY. Biochemical studies in schizophrenia. Schizophr Bull 1976;2:10-8.
3 Tallerico T, Novak G, Liu IS, et al Schizophrenia: elevated mRNA for dopamine D2 (longer) receptors in frontal cortex. Brain Res Mol Brain Res 2001;87:160-5

4 Stefanis NC, Bresnick JN, Kerwin RW, et al. Elevation of D4 dopamine receptor mRNA in postmortem schizophrenic brain. Brain Res Mol Brain Res 1998:53:112-9.

5 Dean B, Hussain T, Hayes W, et al. Changes in serotonin2A and GABA(A) receptors in schizophrenia: studies on the human dorsolateral prefrontal cortex. J Neurochem 1999;72:1593-9.

6 Huttunen $M$. The evolution of the serotonin-dopamine antagonist concept. J Clin Psychopharmacol 1995:15(suppl 1):4S-10S.

7 Dean B. Signal transmission, rather than reception, is the underlying neurochemical abnormality in schizophrenia. Aust N Z J Psychiatry 2000;34:560-9.

8 Dean B, Tomaskovic-Crook E, Opeskin K, et al. No change in the density of the serotonin 1A receptor, the serotonin4 receptor or the serotonin transporter in the dorsolateral prefrontal cortex from subjects with schizophrenia. Neurochem Int 1999;34:109-15.

9 Dean B, Hayes W, Hill C, et al. Decreased serotonin2A receptors in Brodmann's area 9 from schizophrenic subjects. A pathological or pharmacological phenomenon? Mol Chem Neuropathol 1998:34:133-45.

10 Hernandez I, Sokolov BP. Abnormalities in 5-HT2A receptor mRNA expression in frontal cortex of chronic elderly schizophrenics with varying histories of neuroleptic treatment. J Neurosci Res 2000;59:218-25.

11 Dean B, Pavey G, Mcleod M, et al. A change in the density of $\left[{ }^{3} \mathrm{H}\right]$ flumazenil, but not $\left[{ }^{3} \mathrm{H}\right]$ muscimol binding, in Brodmann's area 9 from subjects with bipolar disorder. J Affect Disord 2001;66:147-58.

12 Pralong D, Tomaskovic-Crook E, Opeskin K, et al. Serotonin(2A) receptors are reduced in the planum temporale from subjects with schizophrenia. Schizophr Res 2000;44:35-45.

13 Riley BP, McGuffin P. Linkage and associated studies of schizophrenia. Am J Med Genet 2000;97:23-44.

14 Kouzmenko AP, Scaffidi A, Pereira AM, et al. No correlation between A(-1438)G polymorphism in 5-HT2A receptor gene promoter and the density of frontal cortical 5-HT2A receptors in schizophrenia. Hum Hered 1999;49:103-5.

15 Kouzmenko AP, Hayes WL, Pereira AM, et al. 5-HT2A receptor polymorphism and steady state receptor expression in schizophrenia. Lancet 1997;349:1815.

16 Tandon R. Cholinergic aspects of schizophrenia. Br J Psychiatry Suppl 1999;37:7-1 1

17 Taylor P, Brown JH. Acetylcholine. In: Siegal GJ, Agranoff BW, Albers RW, et al, eds. Basic neurochemistry. Philadelphia: Lippincott-Raven, 1998: $213-42$

18 Breese CR, Lee M, Adams CE, et al. Abnormal regulation of high affinity nicotinic receptors in subjects with schizophrenia. Neuropsychopharmacology 2000;23:351-64.

19 de Leon J, Dadvand M, Canuso C, et al. Schizophrenia and smoking an epidemiological survey in a state hospital. Am J Psychiatry $1995 ; 152: 453-5$

20 Durany N, Zochling R, Boiss KW, et al. Human post-mortem striatal alpha4beta2 nicotinic acetylcholine receptor density in schizophrenia and Parkinson's syndrome. Neurosci Lett 2000;287:109-12.

21 Court JA, Piggott MA, Lloyd S, et al. Nicotine binding in human striatum: elevation in schizophrenia and reductions in dementia with Lewy bodies, Parkinson's disease and Alzheimer's disease and in relation to neuroleptic medication. Neuroscience 2000;98:79-87.

22 Dean B, Crook JM, Opeskin K, et al. The density of muscarinic M1 receptors is decreased in the caudate-putamen of subjects with schizophrenia. Mol Psychiatry 1996:1:54-8.

23 Crook JM, Tomaskovic-Crook E, Copolov DL, et al. Decreased muscarinic receptor binding in subjects with schizophrenia: a study of the human hippocampal formation. Biol Psychiatry 2000;48:381-8.

24 Dean B, Crook JM, Pavey G, et al. Muscarinicl and 2 receptor mRNA in the human caudate-putamen: no change in $\mathrm{ml}$ mRNA in schizophrenia. Mol Psychiatry 2000;5:203-7.

25 Crook JM, Dean B, Pavey G, et al. The binding of [3H]AF-DX 384 is reduced in the caudate-putamen of subjects with schizophrenia. Life Sci 1999:64:1761-71.

26 Deutsch SI, Mastropaolo J, Schwartz BL, et al. A "glutamatergic hypothesis" of schizophrenia. Rationale for pharmacotherapy with glycine. Clin Neuropharmacol 1989;12:1-13.

27 Seeburg PH. The TINS/TiPS lecture. The molecular biology of mammalian glutamate receptor channels. Trends Neurosci 1993; 16:359-65.

28 Ohnuma T, Augood SJ, Arai $\mathrm{H}$, et al. Expression of the human excitatory amino acid transporter 2 and metabotropic glutamate receptors 3 and 5 in the prefrontal cortex from normal individuals and patients with schizophrenia. Brain Res Mol Brain Res 1998;56:207-17.

29 Richardson-Burns SM, Haroutunian V, Davis KL, et al. Metabotropic glutamate receptor mRNA expression in the schizophrenic thalamus. Biol Psychiatry 2000;47:22-8

30 Dean B, Scarr E, Bradbury R, et al. Decreased hippocampal (CA3) NMDA receptors in schizophrenia. Synapse 1999:32:67-9.

31 Gao XM, Sakai K, Roberts RC, et al. lonotropic glutamate receptors and expression of $\mathrm{N}$-methyl-D-aspartate receptor subunits in subregions of human hippocampus: effects of schizophrenia. Am J Psychiatry 2000;157:1141-9.

32 Ibrahim HM, Hogg AJ, Jr, Healy DJ, et al. lonotropic glutamate receptor binding and subunit mRNA expression in thalamic nuclei in schizophrenia. Am J Psychiatry 2000;157:1811-23. 
33 Aparicio-Legarza MI, Davis B, Hutson PH, et al. Increased density of glutamate/N-methyl-D-aspartate receptors in putamen from schizophrenic patients. Neurosci Lett 1998;241:143-6.

34 Healy DJ, Haroutunian V, Powchik P, et al. AMPA receptor binding and subunit mRNA expression in prefrontal cortex and striatum of elderly schizophrenics. Neuropsychopharmacology 1998;19:278-86.

35 Sokolov BP. Expression of NMDAR 1, GluR 1, GluR7, and KA1 glutamate receptor mRNAs is decreased in frontal cortex of "neuroleptic-free" schizophrenics: evidence on reversible up-regulation by typical neuroleptics. J Neurochem 1998;71:2454-64.

36 Ohnuma T, Augood SJ, Arai H, et al. Measurement of GABAergic parameters in the prefrontal cortex in schizophrenia: focus on GABA content, GABA(A) receptor alpha-1 subunit messenger RNA and human GABA transporter-1 (HGAT-1) messenger RNA expression. Neuroscience 1999;93:441-8.

37 Volk DW, Austin MC, Pierri JN, et al. GABA transporter-1 mRNA in prefrontal cortex in schizophrenia: decreased expression in a subset of neurons. Am J Psychiatry 2001;158:256-65

38 Huntsman MM, Tran BV, Potkin SG, et al. Altered ratios of alternatively spliced long and short gamma2 subunit mRNAs of the gamma-amino butyrate type A receptor in prefrontal cortex of schizophrenics. Proc Natl Acad Sci U S A 1998;95:15066-71.

39 Dean B, Sundram S, Bradbury R, et al. Studies on $\left[{ }^{3} \mathrm{H}\right] \mathrm{CP}-55940$ binding in the human central nervous system: regional specific changes in the density of cannabinoid-1 receptors associated with schizophrenia and cannabis use. Neuroscience 2001;103:9-15.

40 Thompson PM, Sower AC, Perrone-Bizzozero NI. Altered levels of the synaptosomal associated protein SNAP-25 in schizophrenia. Biol Psychiatry 1998;43:239-43.

41 Turner KM, Burgoyne RD, Morgan A. Protein phosphorylation and the regulation of synaptic membrane traffic. Trends Neurosci 1999:22:459-64.

42 Webster MJ, Shannon WC, Herman MM, et al. Synaptophysin and GAP-43 mRNA levels in the hippocampus of subjects with schizophrenia. Schizophr Res 2001;49:89-98.

43 Glantz LA, Austin MC, Lewis DA. Normal cellular levels of synaptophysin mRNA expression in the prefrontal cortex of subjects with schizophrenia. Biol Psychiatry 2000;48:389-97.

44 Young CE, Arima K, Xie J, et al. SNAP-25 deficit and hippocampal connectivity in schizophrenia. Cereb Cortex 1998;8:261-8.

45 Davidsson P, Gotffries J, Bogdanovic N, et al. The synaptic-vesicle-specific proteins rab3a and synaptophysin are reduced in thalamus and related cortical brain regions in schizophrenic brains. Schizophr Res 1999:40:23-9.

46 Landen M, Davidsson P, Gottfries CG, et al. Reduction of the small synaptic vesicle protein synaptophysin but not the large dense core chromogranins in the left thalamus of subjects with schizophrenia. Biol Psychiatry 1999;46:1698-702.
47 Honer WG, Falkai P, Chen C, et al. Synaptic and plasticity-associated proteins in anterior frontal cortex in severe mental illness. Neuroscience 1999;91:1247-55.

48 Eastwood SL, Cairns NJ, Harrison PJ. Synaptophysin gene expression in schizophrenia. Investigation of synaptic pathology in the cerebral cortex. BrJ Psychiatry 2000;176:236-42.

49 Sokolov BP, Tcherepanov AA, Haroutunian V, et al. Levels of mRNAs encoding synaptic vesicle and synaptic plasma membrane proteins in the temporal cortex of elderly schizophrenic patients. Biol Psychiatry 2000;48: 184-96.

50 Dale TC. Signal transduction by the Wnt family of ligands. Biochem J 1998;329:209-23

51 Miyaoka T, Seno H, Ishino H. Increased expression of Wnt-1 in schizophrenic brains. Schizophr Res 1999;38:1-6.

52 Kozlovsky N, Belmaker RH, Agam G. Low GSK-3beta immunoreactivity in postmortem frontal cortex of schizophrenic patients. Am J Psychiatry 2000;157:831-3.

53 Beasley C, Cotter D, Khan N, et al. Glycogen synthase kinase-3beta immunoreactivity is reduced in the prefrontal cortex in schizophrenia. Neurosci Lett 2001;302:117-20.

54 Thomas EA, Dean B, Pavey G, et al. Increased CNS levels of apolipoprotein $D$ in schizophrenic and bipolar subjects: implications for the pathophysiology of psychiatric disorders. Proc Natl Acad Sci U S A 2001;98:4066-71.

55 Impagnatiello F, Guidotti AR, Pesold C, et al. A decrease of reelin expression as a putative vulnerability factor in schizophrenia. Proc Natl Acad Sci U S A 1998;95:15718-23.

56 Jarskog LF, Gilmore JH, Selinger ES, et al. Cortical bcl-2 protein expression and apoptotic regulation in schizophrenia. Biol Psychiatry 2000;48:641-50

57 Asherson P, Mant R, McGuffin P. Genetics and schizophrenia. In: Hirsch SR, Weinberger DR, eds. Schizophrenia. Oxford: Blackwell Scientific, 1995: 253-74.

58 Selkoe DJ. Alzheimer's disease: genes, proteins, and therapy. Physiol Rev 2001;81:741-66.

59 Masters CL, Beyreuther K. The Worster-Drought syndrome and other syndromes of dementia with spastic paraparesis: the paradox of molecular pathology. J Neuropathol Exp Neurol 2001;60:317-9.

60 Kuhl M, Sheldahl LC, Park M, et al. The Wnt/Ca2+ pathway: a new vertebrate Wnt signaling pathway takes shape. Trends Genet 2000; 16:279-83.

\section{ANSWERS}

1: $B$ and $C ; 2$ : ; 3 : C; 4: B and D; 5: C and D 